\title{
RANCANG BANGUN SISTEM INFORMASI PERMINTAAN KEBUTUHAN LOGISTIK DI KANTOR WILAYAH II PT PEGADAIAN KOTA PEKANBARU BERBASIS WEB
}

\author{
${ }^{1}$ Muhammad Hidayat, ${ }^{2}$ Zarnelly \\ 1,2Program Studi Sistem Informasi, Fakultas Sains dan Teknologi UIN Suska Riau \\ Jl. HR Soebrantas KM.18 Panam Pekanbaru - Riau \\ Email: ${ }^{1}$ hidayat1995.mh@gmail.com, ${ }^{2}$ zarnelly71@gmail.com
}

\begin{abstract}
ABSTRAK
Kantor wilayah II PT Pegadaian Kota Pekanbaru mempunyai unit bidang yang melayani permintaan kebutuhan kantor cabang dan unit pelayanan cabang yaitu bidang logistik. Permasalahan yang dihadapi dalam proses permintaan kebutuhan logistik antara lain masih menggunakan pembukuan apabila ada surat permohonan permintaan logistik yang masuk, menyebabkan sulit dalam pencarian data ketika dibutuhkan karena harus mencari data pada pembukuan satu persatu dan pada proses persetujuan harus menunggu pimpinan ketika berada di kantor, apabila pimpinan berada diluar kota proses persetujuan harus tertunda dan menyebabkan penumpukan surat permohonan di kantor sehingga terjadi keluhan dari kantor cabang yang mengajukan permohonan karena permintaan yang diajukan tidak ada pemberitahuan dari bidang logistik. Dengan permasalahan yang terjadi dibutuhkan sistem informasi baru yang terhubung dengan kantor cabang untuk dapat membantu mempermudah pekerjaan para pengguna dalam pengelolaan permintaan kebutuhan di bidang logistik yang menjadi solusi dari permasalahan yang terjadi. Sistem informasi permintaan kebutuhan logistik berbasis web ini menggunakan metode analisa dan perancangan Object Oriented Analysis and Design (OOAD) dan Waterfall pada pengembangan sistem dan tools unified modeling language (UML). Hasil uji Black Box yang dilakukan terhadap fitur yang terdapat pada sistem yang dibuat berjalan $100 \%$. Hasil pengujian menggunakan User Acceptance Test (UAT) yang telah dihitung didapatkan persentase hasil akhir kelayakan sistem yang dibangun sebesar $82.29 \%$.
\end{abstract}

Kata kunci: Black Box, Sistem Informasi Permintaan kebutuhan logistik, User Acceptance Test, Object Oriented Analysis and Design, Waterfall.

\section{A. PENDAHULUAN}

PT Pegadaian merupakan Badan Usaha Milik Negara (BUMN) di Indonesia yang bergerak dibidang jasa penyaluran kredit kepada masyarakat atas dasar hukum gadai. Dasar hukum pendirian PT Pegadaian terdapat pada Peraturan Pemerintah Nomor 103 tahun 2000 tentang Perusahaan Umum Pegadaian. PT Pegadaian memiliki 1.112 kantor cabang utama sebagai aset yang tersebar diseluruh Indonesia. Kantor cabang tersebut dikoordinasi oleh 13 Kantor wilayah (Kanwil) yang membawahi 26 sampai 75 Kantor cabang, salah satunya yaitu di Kota Pekanbaru. Kantor wilayah II PT Pegadaian (Persero) Kota Pekanbaru mengkoordinasi 28 Kantor cabang dan 209 Unit pelayanan cabang (UPC) yang tersebar di Provinsi Riau, Provinsi Kepulauan Riau, dan Provinsi Sumatra Barat. Kanwil II PT Pegadaian Kota Pekanbaru mempunyai unit bidang yang melayani permintaan kebutuhan kantor cabang dan unit pelayanan cabang yaitu bidang logistik yang melayani seluruh permintaan kebutuhan perlengkapan kantor, kebutuhan bangunan kantor seperti renovasi atau pembangunan kantor dan kebutuhan perlegkapan kemanan kantor.

Permintaan kebutuhan merupakan proses permintaan sebuah produk barang ataupun jasa yang akan diminta atau dibeli dengan jumlah dan harga tertentu yang harus dipenuhi untuk membantu proses kerja yang lebih baik dalam sebuah organisasi [9]. Seluruh kegiatan permintaan kebutuhan logistik pada PT Pegadaian yang di berada dibawah koordinasi kantor wilayah harus mendapatkan persetujuan dari kantor wilayah untuk pelaksanaan permintaan.

Pada proses pengelolaan informasi permintaan kebutuhan yang berjalan pada Kanwil II PT Pegadaian Kota Pekanbaru pada bidang logistik akan menerima surat permohonan melaui E-mail dari kantor cabang apabila terdapat permintaan kebutuhan logistik yang yang akan dibayar, dibeli ataupun diminta yang diperlukan oleh kantor cabang atau unit pelayanan cabang melalui kantor cabang untuk mendapatkan persetujuan dari pimpinan yang bertanggung jawab dalam proses permintaan kebutuhan logistik yaitu manager logistik, deputi operasional atau pimpinan Kanwil II PT Pegadaian Kota Pekanbaru, dari persetujuan pimpinan tersebut akan dibuatkan surat otorisasi atau pertanggung jawaban dari bidang logistik untuk dilaporkan kepada bidang keuangan Kanwil sebagai perizinan pengiriman biaya yang akan di kirimkan kepada kantor cabang.

Pada proses permintaan kebutuhan logistik yang sedang berjalan masih menggunakan pendataan menggunakan pembukuan apabila ada 
surat permohonan permintaan logistik yang masuk, sehingga sulit dalam pencarian data ketika dibutuhkan karena harus mencari data pada pembukuan satu persatu. Pada proses persetujuan permohonan permintaan kebutuhan di bidang logistik harus menunggu tiga sampai lima hari untuk proses persetujuan dari pimpinan ketika berada di kantor, apabila pimpinan berada diluar kota proses persetujuan harus tertunda karena harus menunggu pimpinan berada di kantor sehingga proses persetujuan permintaan kebutuhan logistik harus tertunda dan membutuhkan waktu lebih dalam prosesnya ke kantor cabang, sehingga terjadi penumpukan surat permohonan di kantor dan keluhan terhadap pihak kantor cabang yang mengajukan permohonan karena permintaan yang diajukan membutuhkan waktu dalam prosesnya karena tidak adanya pemberitahuan dari bidang logistik kanwil apakah surat permintaan kebutuhan sudah dalam tahap proses atau belum.

Tidak adanya proses rekap data permintaan kebutuhan pada bidang logistik sehingga bidang logistik tidak dapat mengetahui secara pasti permintaan kebutuhan yang sering terjadi.

\section{B. LANDASAN TEORI}

\section{B.1. Sistem Informasi}

Sistem merupakan kumpulan elemen-elemen yang saling terkait dan bekerjasama untuk proses masukan yang ditujukan kepada sistem tersebut dan mengolah masukan tersebut sampai menghasilkan kesimpulan yang diinginkan. Informasi merupakan hasil pengolahan data sehingga menjadi bantuk yang penting bagi penerimanya dan mempunyai kegunaan sebagai dasar dalam pengambilan keputusan yang dapat dirasakan akibatnya secara langsung saat itu juga atau secara tidak langsung pada saat mendatang [12].

\section{B.2. Permintaan}

Permintaan adalah sejumlah produk barang atau jasa yang merupakan barang-barang ekonomi yang akan dibeli konsumen dengan haraga tertentu dalam suatu waktu atau periode tertentu dan dalam jumlah tertentu. Demand seperti ini lebih tepat disebut sebagai permintaan pasar (market demand), dimana tersedia barang tertentu dengan harga yang tertentu pula . permintaan adalah sejumlah barang yang diinginkan dan dapat dibeli oleh pembeli [9].

\section{B.3. Perancangan}

Perancangan atau desain sistem dapat didefinisikan sebagai penggambaran, perencanaan dan pembuatan seketsa atau pengaturan dari beberapa elemen yang terpisah ke dalam satu kesatuan yang utuh dan berfungsi [2].

\section{B.4. Waterfall}

Model System Development Life Cycle (SDLC) air terjun atau waterfall sering juga disebut model sekuensial linier atau alur hidup klasik. Model air terjun menyediakan pendekatan alur hidup perangkat lunak secara sekuensial atau terurut dimulai dari analisis, desain, pengodean, pengujian, dan tahap pendukung. Dari kenyataan yang terjadi sangat jarang model air terjun dapat dilakukan sesuai alurnya karena sebab seperti perubahan spesifikasi perangkat lunak terjadi di tengah alur pengembangan, adanya kesulitan bagi pelanggan untuk mendefinisikan semua spesifikasi di awal alur pengembangan.Pelanggan sering kali membutuhkan contoh untuk menjabarkan spesifikasi kebutuhan sistem lebih lanjut, serta pelanggan tidak mungkin bersabar mengakomodasi perubahan yang diperlukan di akhir alur pengembangan. Dengan berbagai kelemahan yang dimiliki model air terjun namun model ini telah menjadi dasar dari model-model lain dalam melakukan perbaikan model pengembangan perangkat lunak [11].

Tahapan dari model waterfall ini dapat dilihat pada Gambar 1.

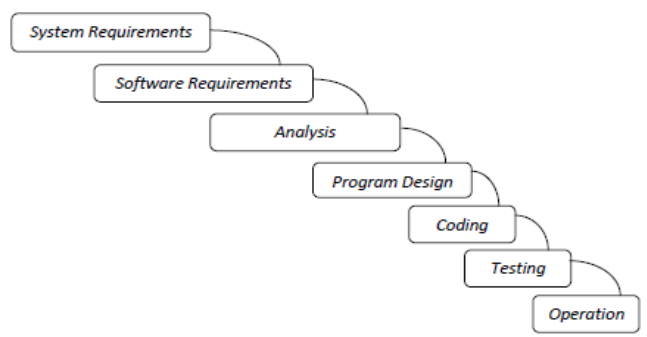

Gambar 1. Tahapan model waterfall[11]

\section{METODOLOGI PENELITIAN}

Metode pengembangan sistem yang digunakan pada penelitian ini adalah waterfall. Ada empat buah diagram unified modeling language (UML) yang digunakan, yaitu: (1) usecase diagram; (2) activity diagram; (3) sequence diagram; dan (4) class diagram.

\section{C.1. System Requirements}

Tahap System requirements dilakukan untuk: (1) Mengidentifikasi masalah; (2) Melakukan studi pustaka; (3) Menentukan batasan masalah; dan (4) Menentukan data yang diperlukan;

\section{C.2. Analysis}

Tahap Analysis dilakukan untuk analisa sistem lama dan rancangan sistem usulan. Analisa sistem lama terdiri dari proses bisnis yang sedang bejalan dan beberapa masalah yang sudah teridentifikasikan sehingga dibutuhkan sebuah sistem iformasi usulan yang akan peneliti bangun. rancangan sistem usulan untuk memberikan sebuah sistem yang akan di bangun dari permasalahan yang terjadi pada sistem lama. 


\section{C.3. Program Design}

Tahap Program design dilakukan untuk (1) Merancang model sistem; (2) Merancang database; (3) Merancang menu struktur; dan (4) Merancang Interface system;

\section{C.4. Coding}

Tahapan coding untuk membangun aplikasi dengan mengimplementasikan hasil dari tahapan Program design ke dalam bahasa pemograman yang dipakai. Masukan pada tahapan ini yaitu informasi aktor, objek dan kelas yang terlibat, sedangkan hasil atau output nya berupa sistem informasi permintaan kebutuhan logistik berbasis web. untuk tahapan ini sumber daya yang digunakan yaitu laptop dengan koneksi internet, Personel Home Page (PHP) sebagai bahasa pemograman dalam pembuatan sistem, dan Notepad ++ sebagai sebagai aplikasi untuk penerapan kodingan.

\section{C.5. Testing dan operation}

Berikut merupakan lingkungan implementasi pada penelitian ini.

\section{1) Sistem berbasis website}

(a) Perangkat keras

- Processor: Intel(R) Core(TM) i3$4005 \mathrm{U}$

- Memory: RAM $3 \mathrm{~Gb}$

(b) Perangkat lunak

- Sistem operasi: Windows 8

- Browser: Chrome

- Bahasa pemrograman: PHP

- Framework: Bootstrap

- Database: MySql

Pengujian aplikasi dilakukan dengan menggunakan metode black box dan user acceptance test (UAT). skenario uji yang digunakan untuk menguji sistem berbasis website.

\section{ANALISA DAN PERANCANGAN}

\section{D.1. Analisa Sistem yang Sedang Berjalan}

Proses sistem yang sedang berjalan pada sistem permintaan kebutuhan logistik di kantor wilayah II PT Pegadaian Kota Pekanbaru pada bidang logistik dapat diuraikan sebagai berikut: (1) Kantor cabang mengajukan surat permohonan dan rincian permintaan kebutuhan kebidang logistik Kantor wilayah II PT Pegadaian Kota Pekanbaru melalui E-mail; (2) Petugas unit kerja bidang logistik menerima surat permohonan dan rincian permintaan melalui E-mail dan mencetak surat permohonan dan rincian untuk didata dan diperiksa oleh bidang logistik apakah anggaran permintaan kebutuhan tersedia apa tidak untuk dilaporkan ke pimpinan yang bertanggung jawab dalam permohonan permintaan untuk proses persetujuan permohonan; (3) Pimpinan melakukan persetujuan surat pemohonan permintaan, Apabila anggaran tersedia surat permohonan disetujui dan apabila anggaran tidak tersedia surat permohonan ditolak. ; (4) Surat permohonan yang sudah dilakukan persetujuan akan dibuatkan surat otorisasi keputusan oleh bidang logistic; (5) Surat otorisasi yang telah dibuat akan ditandatangani oleh pimpinan dan dilaporkan ke bidang keuangan sebagai dasar izin pengiriman biaya permintaan kebutuhan kantor cabang dan mengirim surat otorisasi ke kantor cabang melalui E-mail; (6) Surat otorisasi diterima oleh kantor cabang melalui $E$ mail; (7) Bidang keuangan kantor wilayah melakukan pengiriman biaya kebutuhan kantor cabang apabila surat permohonan disetujui oleh pimpinan; dan (8) Kantor cabang melakukan transaksi pembayaran atau pembelian kebutuhan logistik dan melakukan pendataan pengeluaran biaya dibuku agenda keuangan kantor cabang.

\section{D.2. Rancangan Sistem Usulan}

Perancangan sistem usulan akan memberikan penjelasan dan gambaran yang detail mengenai rancangan kerja dari sistem usulan dalam memenuhi kebutuhan pada bidang logistik dalam pengelolaan informasi. Sistem permintaan kebutuhan logistik ini dikembangkan berbasis web dengan tiga pengguna sistem yaitu: (1) Admin, yang dikelola oleh bidang logistik kantor wilayah; (2) User, yang dikelola oleh kantor cabang; dan (3) Pimpinan, yang dikelola oleh manager logistik, deputi operasional dan pimpinan kanwil. Sistem yang dibangun dapat membantu proses persetujuan yang dapat di lakukan dimana saja menggunakan komputer ataupun smartphone dengan akses internet, sistem yang akan di bangun juga dapat memberikan status dan notifikasi sistem dan $e$ mail.

Beberapa kelebihan yang dimiliki oleh sistem yang dibangun adalah:

1) Sistem dapat memudahkan bidang logistik untuk mengelola data permintaan kebutuhan logistik yang masuk dari kantor cabang.

2) Sistem dapat memudahkan pimpinan yang bertanggung jawab dalam proses persetujuan untuk memberikan persetujuan secara langsung dimana saja menggunakan sistem

3) Sistem dapat memberikan notifikasi informasi berupa email kepada pimpinan apabila terdapat data permintaan untuk dilakukan persetujuan

4) Sistem dapat memberikan notifikasi informasi terhadap pengguna apabila terdapat data yang masuk kedalam sistem

5) Sistem dapat memerikan status kepada pegguna sistem dalam tahap proses permintaan kebutuhan logistik.

6) Sistem dapat memberikan data informasi secara detail.

7) Sistem dapat memberikan tandatangan digital dari pimpinan yang memberikan persetujuan. 
Jurnal Ilmiah Rekayasa dan Manajemen Sistem Informasi, Vol. 5, No. 2, Agustus 2019, Hal. 136-144 e-ISSN 2502-8995 p-ISSN 2460-8181

\section{D.3. Program Design}

Berikut Usecase diagram sistem yang dapat dilihat pada Gambar 2, Class diagram yang dapat dilihat pada Gambar 3 dan Interface Rancangan Beranda sistem yang dapat dilihat pada Gambar 4,
Interface Buat permintaan logistic yang dapat dilihat pada Gambar 5 dan Interface Persetujuan yang dapat dilihat pada Gambar 6 .

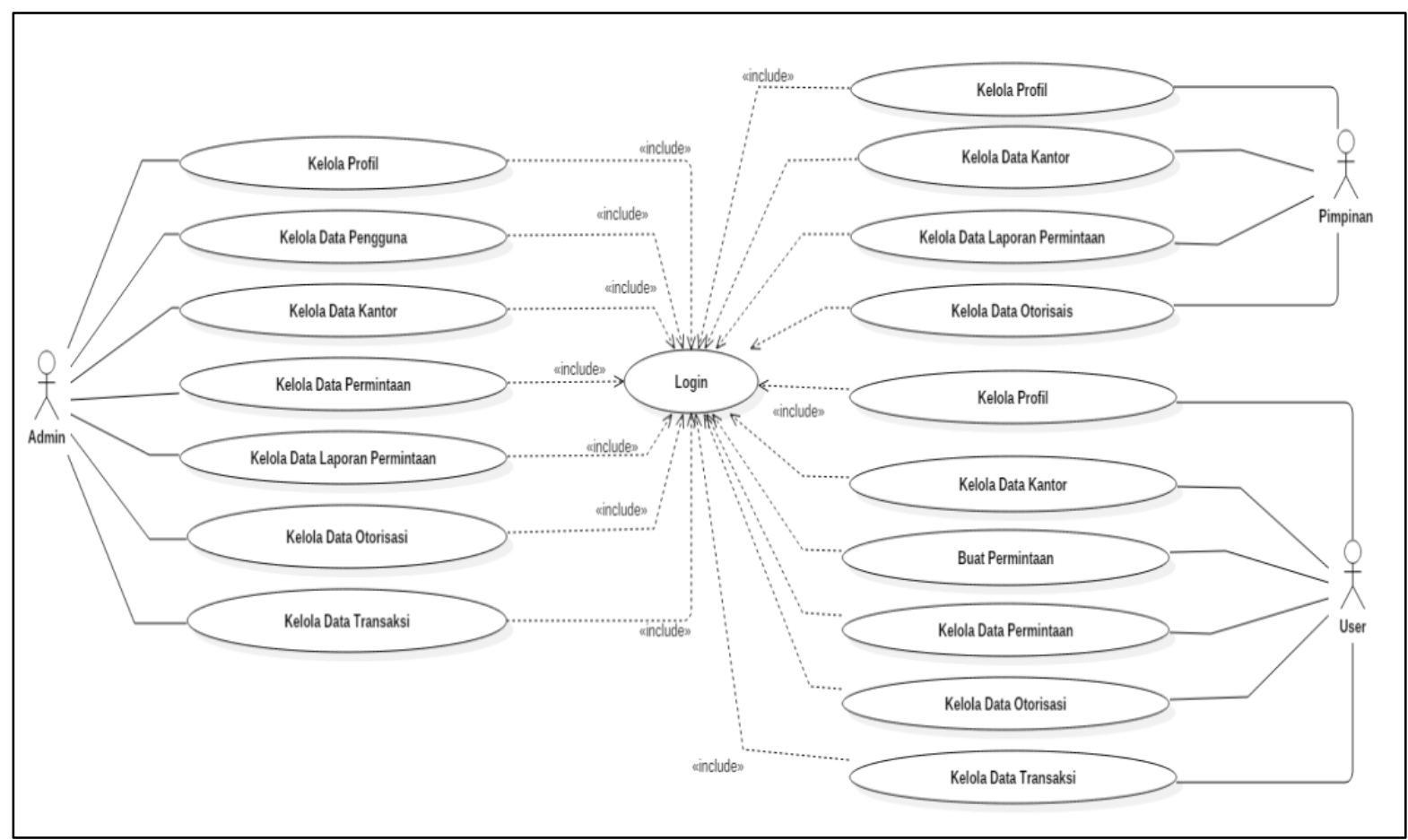

Gambar 1. Usecase Diagram Sistem

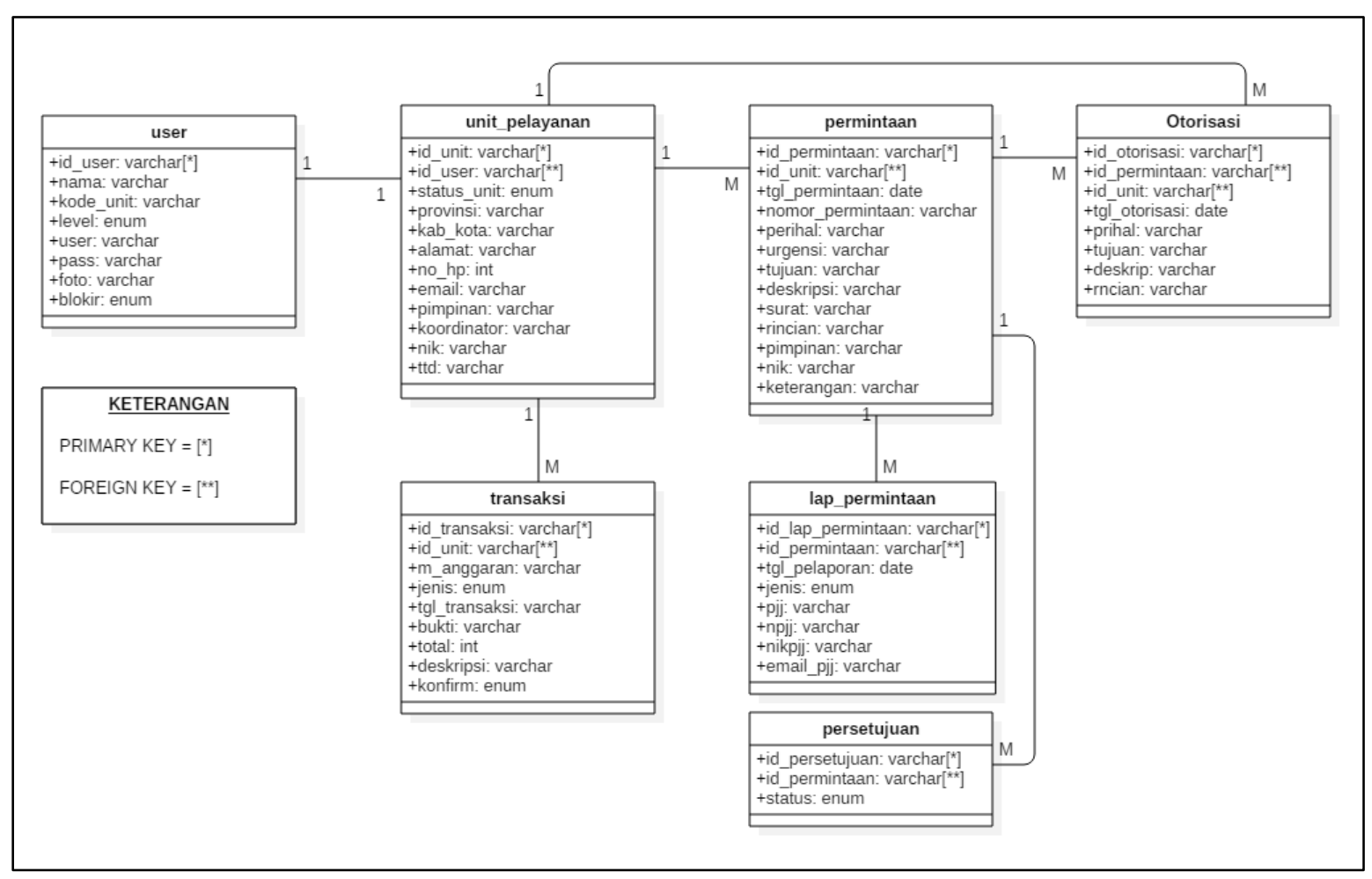

Gambar 2. Class Diagram 


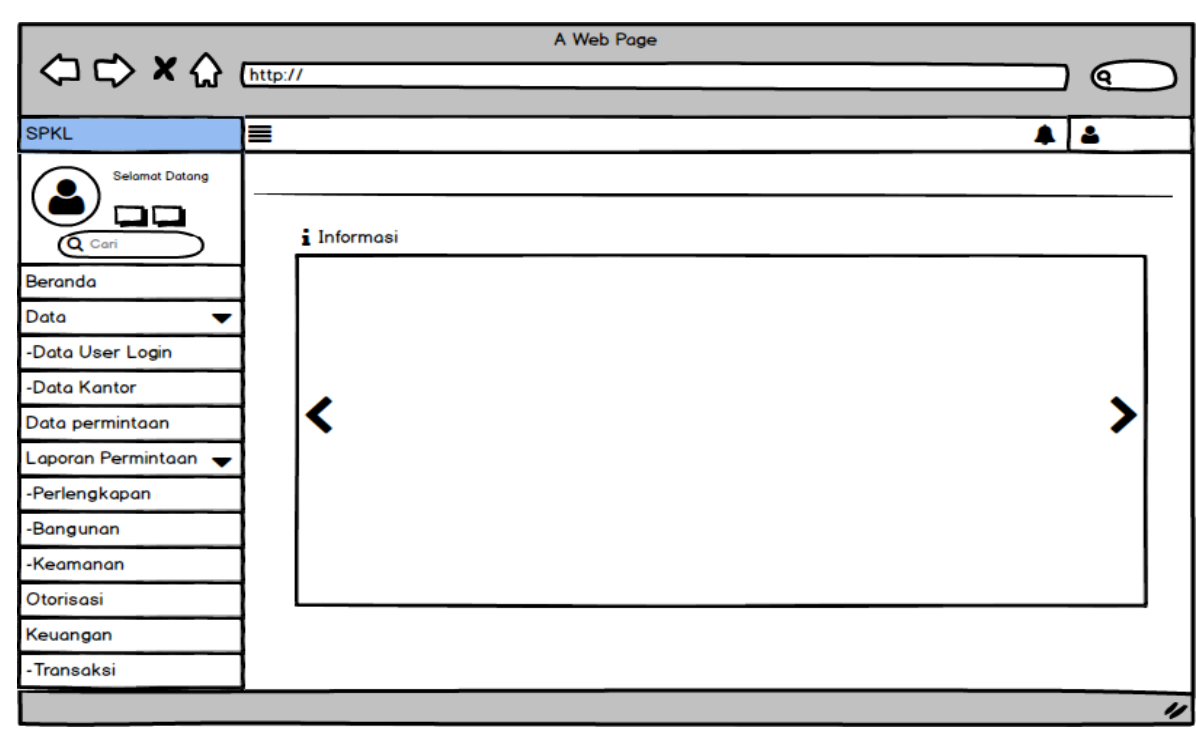

Gambar 4. Interface Beranda Sistem

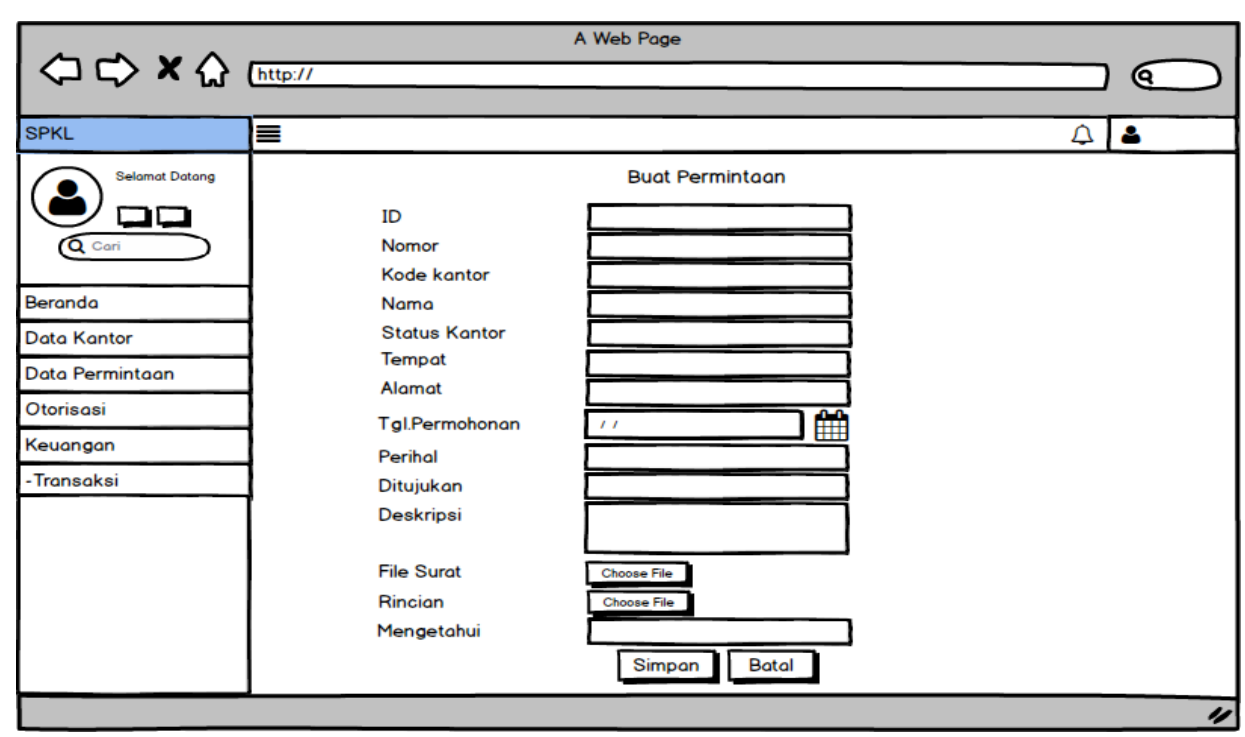

Gambar 5. Interface Buat permintaan Logistik

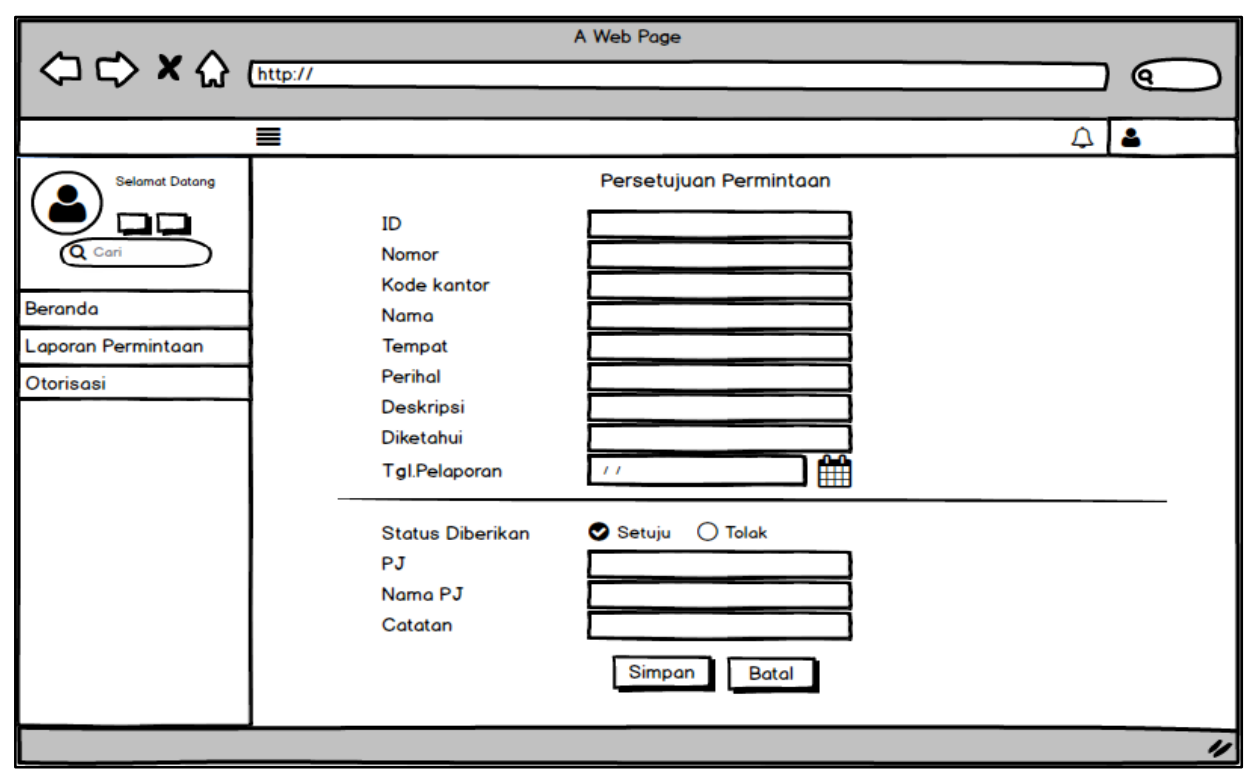

Gambar 6. Interface Persetujuan 


\section{E. HASIL IMPLEMANTASI DAN PENGUJIAN}

\section{E.1. Batasan Implementasi}

Adapun empat batasan implementasi dalam rancang bangun sistem permintaan kebutuhan logistik, antara lain:

1) Sistem yang dibangun merupakan sistem informasi permintaan kebutuhan logistik berbasis web menggunakan metode waterfall.

2) Sistem ini terhubung antara Admin, User, dan Pimpinan.

3) Terdapat hak akses pengguna sistem, yaitu Admin, User, Pimpinan dimana masingmasing pengguna dapat menggunakan sistem sesuai hak akses masing-masing.

4) Sistem diimplementasikan untuk mempermudah dalam proses permohonan permintaan kebutuhan logistik pada kantor cabang dan bidang logistik Kantor wilayah II PT Pegadaian Kota Pekanbaru.

\section{E.2. Lingkungan Implementasi}

Desain sistem yang telah dirancang memerlukan perangkat pendukung yaitu berupa peralatan yang berperan untuk menunjang penerapan sistem pada sistem informasi permintaan kebutuhan logistik seperti perangkat keras (hardware) berupa komputer, laptop atau smartphone dan perangkat lunak (software).

\section{E.2.1. Spesifikasi Hardware}

Processor : Intel(R) Core(TM) i3-4005U

Memory : RAM $3 \mathrm{~Gb}$

E.2.1. Spesifikasi Perangkat Lunak

$\begin{array}{ll}\text { Sistem operasi } & \text { : Windows 7 } \\ \text { Browser } & \text { : Chrome } \\ \text { Bahasa pemrograman } & \text { : PHP } \\ \text { Framework } & \text { : Bootstrap } \\ \text { Database } & \text { : MySql }\end{array}$

Hasil implementasi Halaman Beranda sistem dapat dilihat pada Gambar 7, Halaman Data Permintaan Logistik dapat dilihat pada Gambar 8, Halaman Data Transaksi dapat dilihat pada Gambar 9, dan Halaman Persetujuan dapat dilihat pada Gambar 10

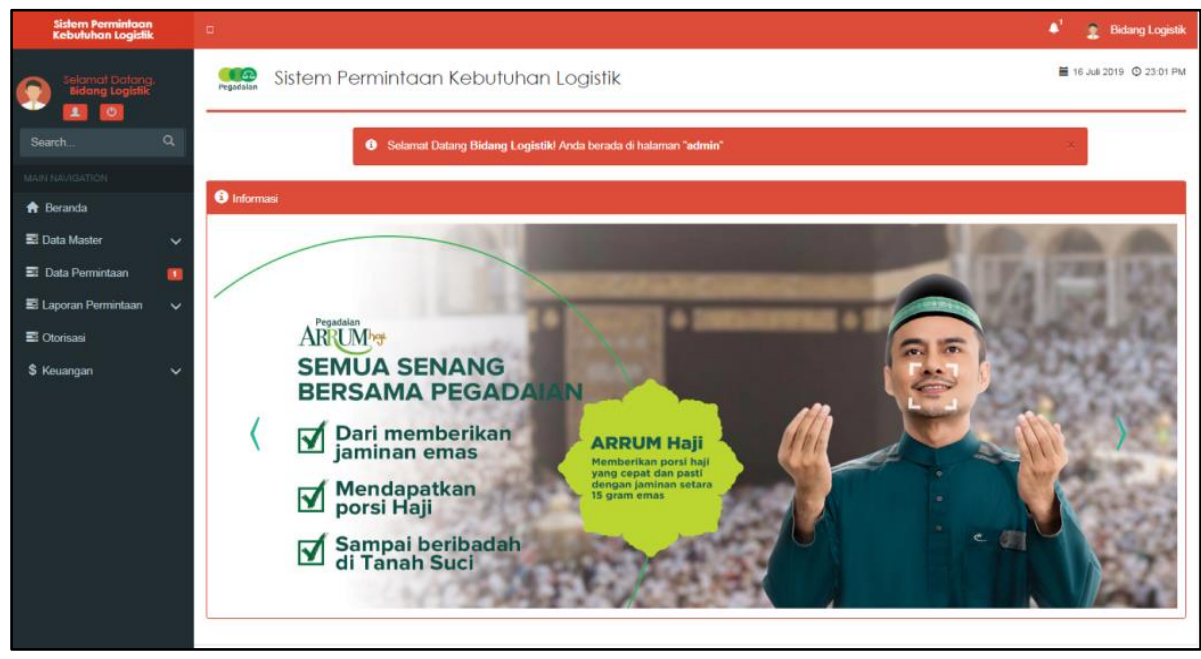

Gambar 7. Halaman Beranda Sistem

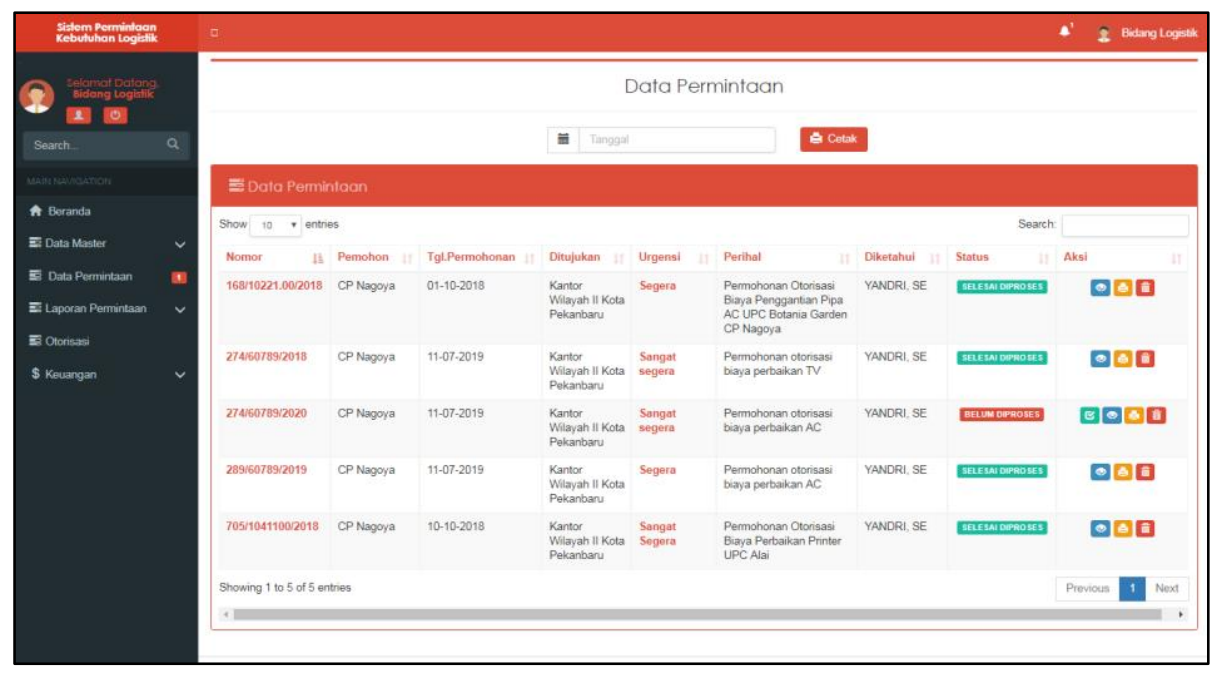


Gambar 8. Halaman Data Permintaan Logistik

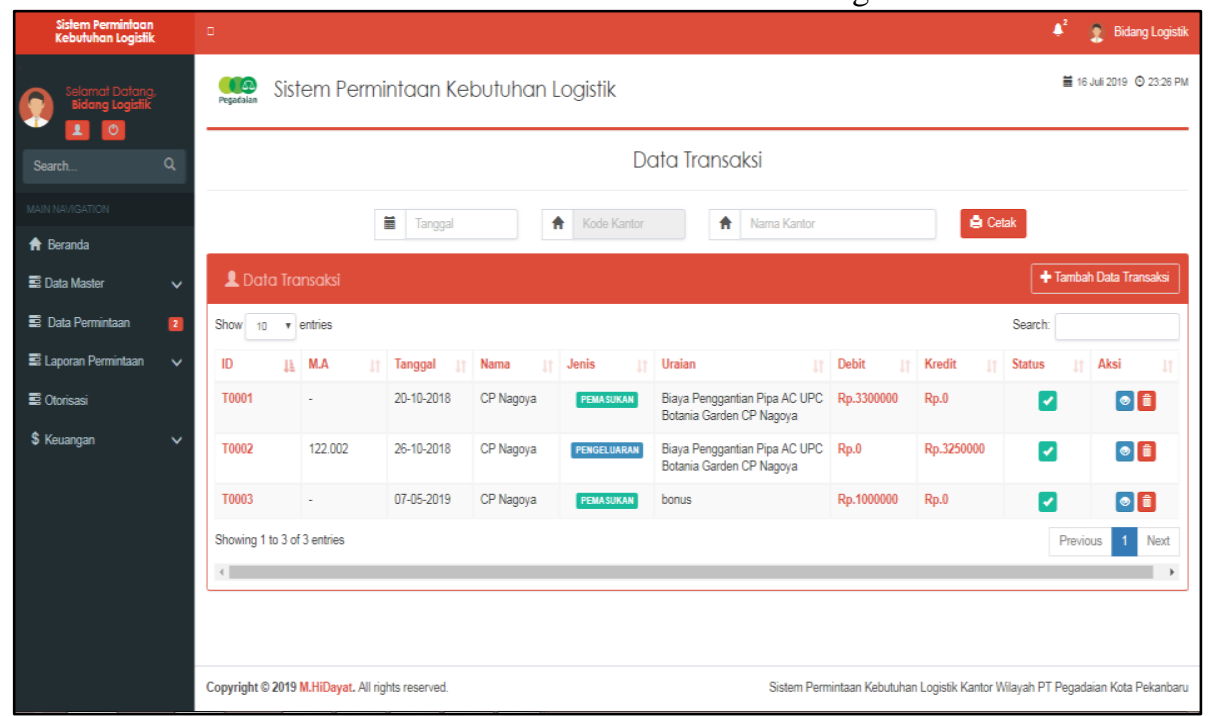

Gambar 9. Halaman Data Transaksi

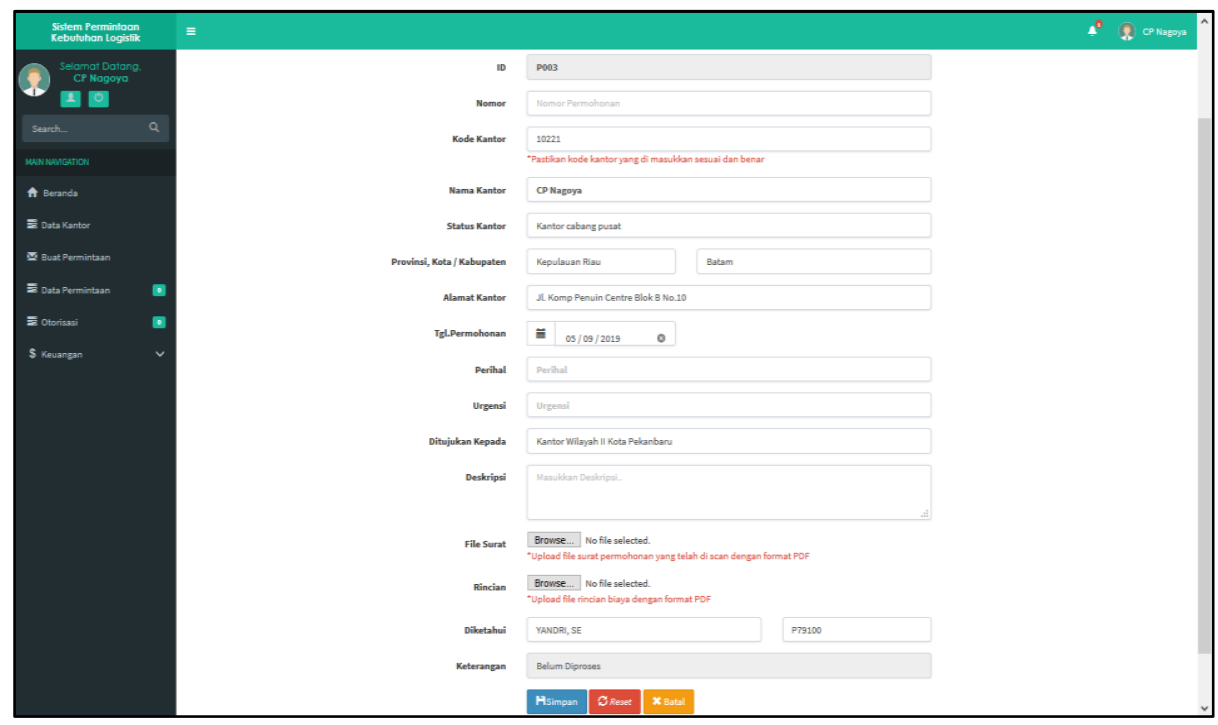

Gambar 10. Halaman Buat permintaan Logistik

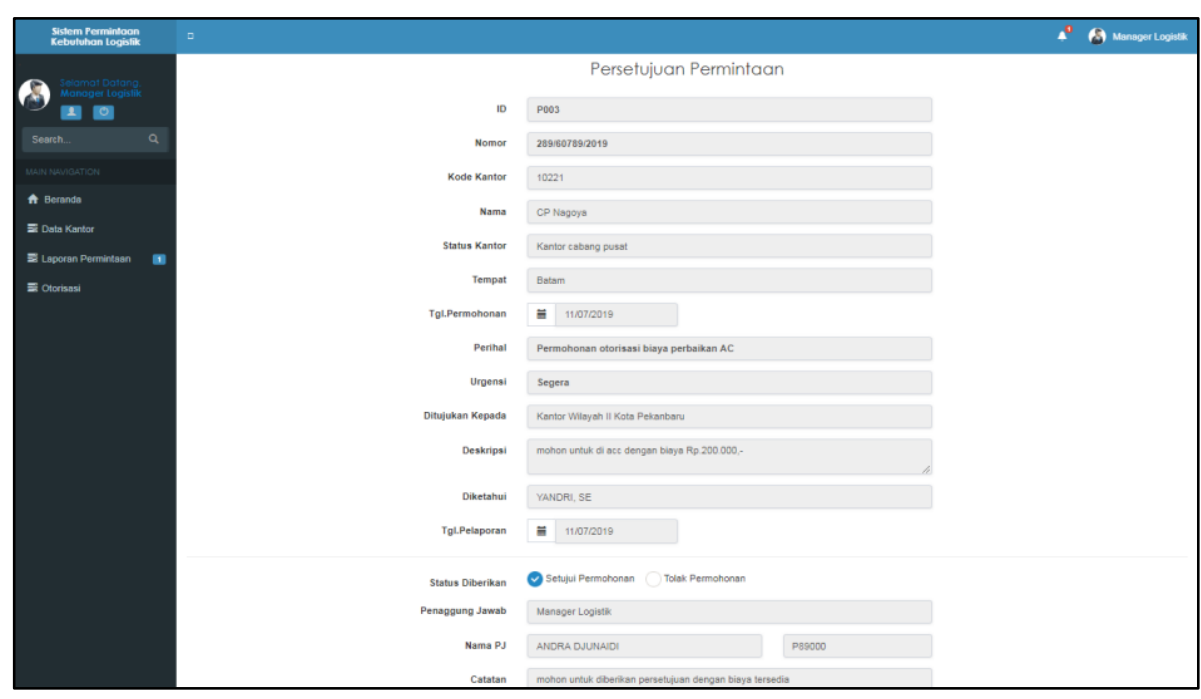

Gambar 11. Halaman Persetujuan 


\section{E.3. Hasil Pengujian}

Hasil pengujian black box menunjukkan bahwa semua fitur yang ada pada sistem permintaan kebutuhan logistik yang dibangun berjalan dengan tingkat keberhasilan $100 \%$.

Hasil pengujian UAT terhadap sistem Permintaan kebutuhan logistik yang dilakukan oleh 15 orang responden dengan jumlah 8 pertanyaan setiap kuisioner UAT menunjukkan tingkat penerimaan yang baik, yaitu $82,29 \%$. Detail hasil pengujian UAT untuk sistem ini dapat dilihat pada Tabel 1.

Tabel 1. Hasil uji UAT Sistem permintaan kebutuhan logistik.

\begin{tabular}{lc}
\hline Pertanyaan & $\begin{array}{c}\text { Tingkat } \\
\text { Penerimaan }\end{array}$ \\
\hline Pertanyaan 1 & $83.33 \%$ \\
Pertanyaan 2 & $80 \%$ \\
Pertanyaan 3 & $80 \%$ \\
Pertanyaan 4 & $90 \%$ \\
Pertanyaan 5 & $85 \%$ \\
Pertanyaan 6 & $80 \%$ \\
Pertanyaan 7 & $80 \%$ \\
Pertanyaan 8 & $80 \%$ \\
Rata-rata & $\mathbf{8 2 . 2 9 \%}$ \\
\hline
\end{tabular}

\section{F. KESIMPULAN DAN SARAN}

\section{F.1. Kesimpulan}

Berdasarkan hasil analisa, perancangan serta pengujian maka dapat disimpulkan, yaitu: (1) Penelitian ini berhasil merancang dan membangun sistem informasi permintaan kebutuhan logistik baru berbasis web menggunakan metode waterfall di bidang logistik pada Kantor Wilayah II PT.Pegadaian Kota Pekanbaru; (2) Dengan adanya sistem informasi permintaan kebutuhan logistik dapat direkomendasikan untuk mempermudah pekerjaan pada proses permintaan kebutuhan logistik dan meningkatkan layanan informasi di bidang logistik Kantor wilayah II PT Pegadaian Kota Pekanbaru; (3) Berdasarkan hasil pengujian menggunakan Black Box yang dilakukan dapat disimpulkan bahwa fitur yang terdapat pada sistem permintaan kebutuhan logistik $100 \%$ dapat berjalan dengan baik; dan (4) Berdasarkan hasil perhitungan menggunakan User Acceptance Test yang telah dihitung, maka didapatkan persentase hasil akhir kelayakan sistem yang dibangun adalah sebesar $82.29 \%$;

\section{F.2. Saran}

Saran yang dapat membangun, penulis menyarankan untuk sistem informasi permintaan kebutuhan logistik penelitian yang akan datang sebagai berikut: (1) Diharapkan sistem ini dapat dikembangkan dalam bentuk aplikasi mobile berbasis android sehingga lebih mudah untuk di akses menggunakan smartphone; (2) Menyediakan fitur chat online atau costumer service sehingga pengguna sistem dapat melakukan tanya jawab mengenai permintaan kebutuhan logistik apabila terdapat permasalahan; dan (3) Pada pengembangan selanjutnya diharapkan dapat menambahkan hak akses kebidang keuangan secara detail sehingga fungsi sistem lebih efektif dan efisien dalam pelaporan keuangan.

\section{REFERENSI}

[1] Jogiyanto, 2001. "Analisis dan Desain Sistem Informasi : PendekatanTerstruktur Teori dan Praktek Aplikasi Bisnis." Penerbit Andi: Yogyakarta.

[2] Jogiyanto, 2005. "Analisa Dan Desain Sistem Informasi”. Penerbit Andi: Yogyakarta.

[4] Kendall, K.E. dan Kendall, J.E. 2003. Analisis dan Perancangan Sistem. (B. M. Thamir Abdul Hafedh Al-Hamdany, Penerj.) Jakarta: Pearson Education Asia Pte. Ltd. dan PT. Prenhallindo.

[5] Raharjo, Budi. 2011. "Belajar Otodidak Membuat Database Menggunakan MySQL". Informatika Bandung: Bandung.

[6] Sholiq, 2006. "Pemodelan Sistem Informasi Berorientasi Objek Dengan UML". GrahaIlmu: Yogyakarta.

[7] Siagian Yolanda, 2005. "Aplikasi Supply Chain Management Dalam Dunia Bisnis". Penerbit Grasindo: Jakarta.

[8] Tantra, Rudy. 2012. "Manajemen Proyek Sistem Informasi". Penerbit Andi:: Yogyakarta.

[9] An'im Fattach. "Teori Permintaan dan Penawaran dalam Ekonomi Islam”. Jurnal Penelitian Ilmu Manajemen. Volume II No. 3. ISSN : 2502-3780. 2017.

[10] Benny, Mutiara, dkk. "Testing implementasi website rekam medik elektronik ipeltgunasys dengan metode acceptance testing”. Prosiding Seminar Ilmiah Nasional Komputer dan Sistem Intelijen. Vol 8. ISSN:2302-3740. 2014.

[11] Dinanta, Rangga. "Rancang Bangun Aplikasi Workflow Persetujuan Permintaan Kebutuhan Workshop Pada Departemen Hse (Health, Safety, Environment, dan Module And Training) PT. Bangun Sarana Baja". Tugas Akhir: Institut Bisnis Dan Informatika Stikom Surabaya. 2016.

[12] Gallaleo I. Wibowo, A. M. Rumagit, ST., MT. dan N. J. Tuturoong, ST., M.Kom. "Perancangan Aplikasi Gudang Pada PT. Pakan Ternak Sejati”. Jurnal Teknik Elektro dan Komputer. ISSN : 2301-8402. 2014.

[13] Nugroho, Angga Adi, dkk. 2010. "Pengembangan Sistem Informasi 
Pembelian Barang (Studi Kasus: PT. Tiara Royale Pada Departemen Purchasing And Store Order)". Jurnal Sistem informasi. PISSN: 1979-0767. 2010.

[14] Nurlaila Hasyim, Nur Aeni Hidayah dan Sarwoto Wijoyo Latisuro. "Rancang Bangun Siste Informasi Koperasi Berbasis Web Pada Koperasi Warga Baru MTsN 17 Jakarta”. Jurnal Sistem Informasi. ISSN:1979-0767.. 2014.

[15] Pranata, Galih Ariadhi, dkk. "Rancang bangun sistem informasi permintaan pembelian barang berbasis web di STEMIK STIKOM Surabaya". Jurnal JSIKA. Vol. 3, No.1. ISSN:2338-137X. 2014.

[16] Ratnawati. "Pengembangan Aplikasi Profil Sekolah Berbasis Augmented Reality Sebagai Media Informasi Profil Sekolah Di Sma Negeri 1 Wonogiri". Skripsi: Universitas Gunadarma. Yogyakarta. 2016.

[17] Tabrani, Muhammad, dkk. "Penerapan Metode Waterfall Pada Sistem Informasi Inventori PT.Pangan Sehat Sejahtera". Jurnal Inkofar. Vol.1, No.2. ISSN:26153645. 2017.

[19] Tukino. "Pengaruh Kualitas Sistem Informasi Manajemen Dan Struktur Organisasi Terhadap Efektivitas Pengambilan Keputusan Pada PT UT Quality Indonesia”. Jurnal Sistem Informasi. Volume 2 No 1. ISSN 2337-8794. 2014.

[20] Wardatul Jannah, Indah Fitri Astuti dan Septya Maharani. "Rancang Bangun Sistem Informasi Bimbingan Belajar Berbasis Web". Jurnal Sistem Informasi Mulawarman. Vol.10 No.1 2015.

[21] Zarnelly, dan Adelia, D. "Rancang Bangun Media Pelayanan Umum Desk Info Di Pengadilan Tinggi Agama Pekanbaru”. Jurnal Informatika. Vol.14, No.1. ISSN 2502-8995. 2014.

[22] Definisi PT Pegadian, https://www.pegadaian.co.id/. Diakses pada tanggal 20 September 2018. 